the whole instruetive and attractive. The part taken by Basle in the development of science, learning and industry is explained, but the field covered is generally wider, the development of science and industry from early times in many lands being dealt with. The style is in general non-technical. The main interest of the publication is the wealth of illustrative material.

\section{National Research Council of Canada Scholarships}

THE National Research Council of Canada has granted 486 scholarships for 1960-61, with a total value of $1,040,000$ dollars; of these 423 are for graduate work at Canadian universities. These include 140 bursaries worth 1,800 dollars each, and 283 studentships worth 2,200 dollars each. Awards for study in other countries include 34 special scholarships worth 2,200 dollars each. 27 of these are to be held in the United Kingdom, and 7 in the United States. 29 postdoctorate overseas fellowships, valued at 3,500 dollars for married and 2,700 dollars for single Fellows, have been granted for work in the following countries : 21 in the United Kingdon ; 2 in Australia ; 2 in France and 2 in Germany; 1 in Belgium and 1 in the Netherlands.

\section{Manchester Literary and Philosophical Society}

The Manchester Literary and Philosophical Society announces the election of officers and committee as follows : president, Prof. H. Lipson ; vice-presidents, Miss A. C. Alexander, Sir Geoffrey Jefferson, Mr. F. G. Glossop, Prof. R. D. Waller; honorary secretaries, Dr. G. T. Ashley, Dr. L. Cohen; honorary treasurer, Mr. H. Hayhurst; honorary librarians, Mr. L. L. Ardern, Dr. W. H. Brindley; honorary curator, Dr. J. A. Petch; council, Mr. L. Cohen, Mr. A. H. Coulty, Mr. S. M. Milner, Mr. N. G. C. Pearson, Miss M. Pilkington, Mr. M. P. Pariser, Mr. B. Rodgers, Mr. F. C. Toy, Mr. C. E. Young.

\section{The Institution of Metallurgists}

Mr. W. E. BARDGETT, research manager of the United Steel Companies, Ltd., was elected president of the Institution of Metallurgists in succession to Prof. A. J. Murphy. The following appointments to officers and council are also announced : presidentelect, Dr. N. P. Allen (National Physical Laboratory) vice-presidents, E. A. Bolton (I.C.I., Motals Division), and E. G. West (Aluminium Development Associa. tion); honorary treasurer, L. W. Derry (Battersea College of Technology); members of council, I. Jenkins (General Electric Co., Ltd., Wembley, Middlesex), Dr. A. H. Sully (British Steel Castings Research Association, Sheffield), Prof. C. R. Tottle (University of Manchester) and E. Mitchell (Lucas Group Research Centre, Birmingham).

\section{The Institute of Mining and Metallurgy: Awards}

THE following awards of the Institute of Mining and Metallurgy are announced: Gold Medals, to Mr. E. D. MeDermott, in recognition of his services to the mining industry and profession, and of his services to the Institution as its representative on the Governing Body of the Imperial College of Science and Technology for fifteen years; and to Mr. J. Kruttschnitt, in recognition of his services to the mining industry in Australia; Honorary Membership, to the Right Hon. Lord Robins, in recognition of his services to the mineral industry, particularly in southern Africa ; to Sir Patrick Linstead, in recognition of his services to the profession of mining and metallurgical engineering in the field of education. and to George Augustus Whitworth, in recognition of his services to the mining industry and profession on the occasion of his retirement from the principalship of the Camborne School of Metalliferous Mining.

\section{Announcements}

Dr. Gerald B. Cook has been appointed ehief chemist of the International Atomic Energy Agency. Dr. Cook, a graduate of the University of Birmingham, has worked at the Cavendish Laboratory, the Canadian atomic energy project in Montreal and at Chalk River, and at the Atomic Energy Research Establishment at Harwell, first in the Chemistry Division and from 1954 as head of the Chemistry Group of the Isotope Research Division.

THe Challenger Society is prepared to make small grants for research in marine biology or oceanographyat a recognized laboratory during the year June $1960 / 61$. Applications, accompanied by details of the proposed research, should reach the Hon. Secretary, Challenger Society, National Institute of Oceanography, Wormley, Godalming, Surrey, not later than June 30.

"The Register of Current Scientific Research at South African Universities, 1959" is based on replies to questionnaires, and the 587 entries are printed as received, English translations being provided for Afrikaan entries (edited by D. Ryle Masson. Pp. vii+113. Pretoria: South African Council for Scientific and Industrial Research, 1960). The material is arranged under nine main headings, with sub-divisions, and in the sub-divisions under the university alphabetically. The Register is well printed and most entries are provided with a brief description of the scope of the research. There are author and subject indexes.

A Booklet published by the Biochemical Society, copies of which are obtainable from Mr. R. E. Sherriff, 133-5 Oxford Street, London, W.1, explains for the benefit of school-leavers what biochemistry is about, how one can train to become a biochemist and the opportunities and prospects that exist for a biochemist (Careers in Biochemistry. Pp. 8. London: Biochemical Society, 1960. 8d.). Some of the information has already appeared in the publications, "Biology as a Career" and "Looking to Chemistry for a Career", of the Institute of Biology and the Royal Institute of Chemistry, respectively, and to these publications prospective biochemists are referred for fuller information.

"Civilian Application Releases through 1959", issued by the Technical Information Division, Sandia Corporation, gives a cumulative bibliography of technical reports, memoranda and manuscripts, including a section on engineering materials (drawings and specifications) released from the Atomic Energy Corporation's Engineering Materials Branch at Oak Ridge (pp. 88. Washington, D.C. : Office of Technical Services, Department of Commerce, 1960. 2.25 dollars). Prices for printed, or photostat, or microfilm copies are listed for many of the entries. There are some $\mathbf{9 0 0}$ entries arranged numerically. 